\title{
US budget 'freezes' spending on research
}

[WASHINGTON] Hopes of substantial increases in science spending in the United States suffered a major setback this week. President Bill Clinton's proposed budget for fiscal year 2000 would essentially freeze spending on research and development in the largest science agencies at 1999 levels.

Clinton proposed a 2 per cent increase at the National Institutes of Health (NIH), the lowest for this agency for many years, and a reflection of what the administration - and some outside - consider to be the excessive 15 per cent boost that NIH received last year.

The National Science Foundation (NSF), which supports most non-biomedical research at US universities, did better than other agencies, with an increase in its research budget of almost 7 per cent. But more than half of that will support a new, multi-agency initiative in information technology, leaving most research directorates at NSF with increases below 3 per cent.

The outlook was even bleaker at other agencies that fund university research, such as the Department of Defense, which plans to reduce its research budget by 4 per cent.

These cuts, and additional reductions in military development and testing, mean that the total amount of money for research and development in Clinton's 2000 budget would decline slightly, from $\$ 79.2$ billion to $\$ 78.2$ billion. However, the proposal would meet the administration's long-standing objective that civilian and military research and development should be funded equally. When Clinton came to power in 1993, military work consumed 60 per cent of the total.

Research lobbyists reacted with disappointment to an overall budget less auspicious than the one hinted at by extensive leaks preceding Monday's announcement. "We're disappointed that the president chose not to continue the momentum he helped to create last year," says William Brinkley, vice-president of the Baylor College of Medicine in Houston, Texas, and current president of the Federation of American Scientists for Experimental Biology. "This sends a terrible message to young investigators."

But Brinkley was confident that the bio-

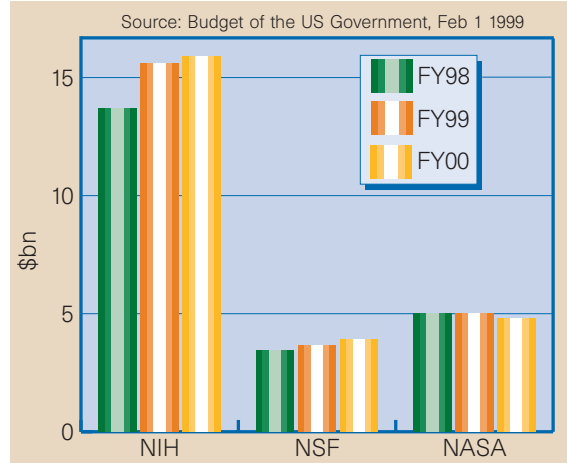

Proposed R\&D spending at top science agencies.

\section{Highlights of the budget request for 2000}

The budget of the National Institutes of Health $(\mathrm{NHH})$ will increase by $\$ 320$ million, or 2.1 per cent, to $\$ 15.9$ billion

The major $\mathrm{NH}$ institutes will each receive increases at around that level - just enough to cover inflation. $\mathrm{NHH}$ says the proposal would allow it to support 7,617 new investigative grants in the fiscal year 2000, compared with the 9,171 grants that it will issue this year.

\section{The National Science}

Foundation fares best of the large agencies, with a proposed increase of $\$ 250$ million, or 6.9 per cent, taking its budget close to $\$ 4$ billion.

As well as the new computing initiative, costing $\$ 146$ million, the agency plans a new $\$ 50$ million programme in biocomplexity - a favourite subject of Rita Colwell, its new director.

The Department of Energy's $\$ 2.8$ billion request for science is $\$ 138$ million more than last year. The largest increases go to the new supercomputing initiative (\$70 million) and to advance construction of the Spallation Neutron Source facility at the
Oak Ridge National Laboratory in Tennessee (\$214 million). High-energy physics (\$697 million), nuclear physics (\$343 million) and fusion (\$223 million) remain essentially flat.

NASA's budget dips less than one per cent to $\$ 13.58$ billion, with space science (\$2.2 billion), life and microgravity science (\$256 million) and Earth science (\$1.46 billion) all hovering around last year's levels. New science initiatives include a communications relay for Mars-orbiting spacecraft and a low-cost Mars 'airplane' to scout sample return sites.

\section{The Department of} Defense, which remains the most important sponsor of US university research in computer science and engineering, will freeze its investment in basic research at $\$ 1.1$ billion, and sharply cut applied research by $\$ 200$ million, to less than $\$ 3$ billion. The Pentagon's expenditure on development and testing will also fall sharply, despite generous increases in total military spending.
The National Institute of Science and Technology is seeking to raise the budget of its Advanced Technology Program by $\$ 40$ million, to $\$ 240$ million, and wants over $\$ 100$ million for new laboratories, mainly the Advanced Measurement Laboratory, under construction at Gaithersburg, Maryland.

The $\$ 535$ million request for research and development at the Environmental Protection Agency is about the same as last year's budget, after factoring out congressional 'earmarks'. Small increases go to climate change research, investigating the health effects of particulate matter, coastal environmental monitoring, and assessment of human health risks.

The budget of the US GeologicalSurvey would climb 5 per cent to $\$ 838.5$ million, with extra funds for a disaster information network, amphibian research and monitoring, and public use of geophysical data. medical research lobby can still persuade Congress to grant another 15 per cent increase this year for NIH. Neal Lane, Clinton's science advisor, defended the 2 per cent increase at NIH, pointing out that it would take the agency's 2000 budget to the level proposed by the administration a year ago, before Congress granted this year's increase.

The budget proposal for the space agency NASA contains few surprises, but enough money to maintain existing science projects. Dan Goldin, NASA's administrator, once again touted his agency as a model of government 'reinvention', saying: "For the sixth year in a row, NASA's budget has declined while productivity improves."

The most important fresh research initiative was the $\$ 366$ million, multi-agency information technology scheme announced last month by vice-president $\mathrm{Al}$ Gore (see Nature 397, 285; 1999). Rita Colwell, director of the NSF, which will lead the initiative, pledged that all disciplines that use supercomputer modelling would be boosted. "All of science is going to benefit from this, and funds will go to the best proposals that come in," she said.

The administration requests $\$ 1.8$ billion for the second year of its Climate Change Technology Initiative, an increase of onethird. The total includes $\$ 400$ million of tax credits. Most of the money would go to the Department of Energy, to develop renewable and fossil-fuel energy sources and promote energy-efficient technology. But $\$ 32$ million of it is for scientific research, including work on microbes that could sequester carbon to help meet greenhouse-gas reduction targets.

The Environmental Protection Agency's share in the climate initiative rises from $\$ 109$ million last year to $\$ 216$ million, most going to develop energy-efficient technologies and for tax incentives for decreasing energy consumption.

Colin Macilwain \& Tony Reichhardt 